\title{
Pilot Scale Froth Flotation Studies To Upgrade Nigerian Itakpe Sinter Grade Iron Ore To A Midrex-Grade Super-Concentrate
}

\author{
${ }^{1 *}$ Ola, S. A., ${ }^{1}$ Usman G.A., ${ }^{1}$ Odunaike, A.A., ${ }^{2}$ Kollere, S.M., ${ }^{1}$ Ajiboye, P.O., ${ }^{3}$ Adeleke, A. O. \\ ${ }^{1}$ National Metallurgical Development Centre (NMDC), P.M.B. 2116, Jos, Nigeria. \\ *E-mail:solomonaola@yahoo.com \\ ${ }^{2}$ Raw Materials Research and Development Council, Abuja, Nigeria. \\ ${ }^{3}$ Department of Materials Science and Engineering, Obafemi Awolowo University, \\ Ile-Ife, Nigeria.
}

\begin{abstract}
The sinter grade concentrate of Itakpe iron ore found in the North Central Kogi state of Nigeria

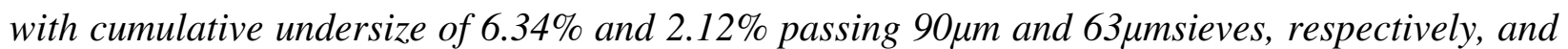
that assayed $63.63 \% \mathrm{Fe}, 5.90 \%$ silica and $0.72 \%$ alumina was ground in ball mill to produce a pilot plant froth flotation feed with cumulative undersize of $74.37 \%$ and $42.94 \%$ for $90 \mu \mathrm{m}$ and $63 \mu \mathrm{m}$ sieves, respectively. The ball mill discharge was then treated in three stages of roughing, cleaning and re-cleaning in a pilot plant froth flotation process line and the products obtained gave 66.66\%, 66.51\%, 65.44\% (Fe) and total acid (silica and alumina) contents of 4.22\%, $4.39 \%, 5.15 \%$, respectively, for the three stages. The super-concentrate obtained also gave

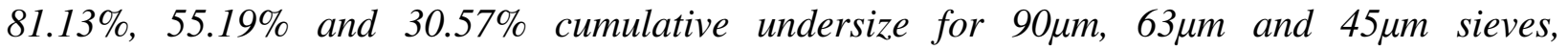
respectively. The results obtained showed that the roughing stage of the flotation process produced a super-concentrate that fall in the range of $66 \%$ to $68 \%$ for use in midrex direct reduction plant at the Delta Steel Plant, Nigeria. The lowest total acid gangue content of $4.22 \%$ was also obtained for the roughing stage, indicating that the two subsequent processes of cleaning and re-cleaning were not needed. Although, the total acid content of $4.22 \%$ for the roughing stage product slightly exceeds the upper limit of $3.50 \%$ for the Midrex process, Itakpe sinter grade concentrates with up to $5 \%$ acid gangue has been successfully used at the Delta Steel Plant Midrex plant.
\end{abstract}

Key Words: sinter, middrex, concentrate, froth flotation, super-concentrate 


\section{INTRODUCTION}

Itakpe iron ore deposit, with an estimated reserve of about 200 million tons was found in 1977. The deposit is embedded in the Itakpe hill, near Okene, in the north central Kogi state of Nigeria. The deposit extends approximately 3,000m in length and includes about 25 layers of ferruginous quartzite. From a tectonic point of view, the Itakpe deposit is confined to the southern limb of a large Itakpe-Ajabanoko anticline with enclosing rocks and conformable ore layers striking sublatitudinally slightly bending to the North and dipping southwards at angles ranging from $40^{\circ}$ to $80^{\circ}$ with local complications like minor folds. The deposit contains a mixture of magnetite and hematite whose ratio varies throughout the deposit. The ore consists of coarse, medium and fine grained particles. The fine ores are mainly in the eastern part of the deposit and in the thin layers, while the coarse and medium ores are relatively mixed. However, the coarse ore particles predominate in the north and west of the central layers and the medium sizes in the centre of the central layers. The average content of iron in the ore is approximately $35 \%$.[1]

The Nigerian National Iron Mining Company Ltd. (NIOMCO), Itakpe, was established to upgrade Itakpe iron ore to sinter grade of $63 \%$ to $64 \% \mathrm{Fe}$ for the blast furnace based Ajaokuta integrated steel plant, Ajaokuta, Kogi state. The Itakpe sinter grade concentrate is however not suitable for direct reduction operations at the Delta Steel Company (DSC), Aladja, Delta state, Nigeria, and needs to be up-graded to a superconcentrate grade with $66 \%$ to $66.88 \% \mathrm{Fe}$. The world production of direct reduced iron (DRI) has increased from 1 million tons in 1970 to 40 million tons currently. The Midrex process has accounted for over $60 \%$ of the annual worldwide DRI production.[2] Steelmaking slag contains calcium oxide, magnesium oxide, silica, alumina and other compounds in smaller concentrations. Pure silica has a very high viscosity, but the addition of other metal oxides, except alumina, reduces the viscosity. The preferred characteristic for DRI grade pellets is typically $67 \% \mathrm{Fe}$ (minimum) and $3.0 \%$ (maximum) silica + alumina+ Titanium oxide.[3]

Froth flotation is a physico-chemical method of concentrating ground ores. The process involves chemical treatment of an ore pulp to create conditions favourable for the attachment of predetermined mineral particle to air bubbles carrying the selected minerals to the surface of the pulp, there forming a stabilized froth which is skimmed off and from which the pre-determined mineral particles are recovered. Other minerals remain sub-merged in the pulp.[4]

The market requirements for higher grade concentrates of iron to improve the productivity of the blast furnace has increased the importance of flotation process with respect to the conventional pre-concentration of iron ore by gravity or magnetic methods. The flotation method commonly applied is the one based on cationic flotation of silica and silicates, that is, reverse flotation [5]. The reagents required for froth flotation are collectors, frothers and regulators, such as activators and depressants. Collectors adsorb on mineral surfaces, rendering them hydrophobic and 
facilitating bubble attachment. The frothers help maintain a reasonably stable froth. Regulators are used to control the flotation process to either activate or depress mineral attachment to air bubbles and are also used to control the $\mathrm{pH}$ of the slurry.[6]

The aim of this study is to obtain pilot scale froth flotation process parameters to upgrade the Itakpe iron ore sinter grade to a super-concentrate that meet the physical characteristics of less than $30 \%$ passing $45 \mu \mathrm{m}$ that will not pose transportation and handling problems at DSC. The study involved physical and chemical characterization of Itakpe iron ore sinter concentrate and pilot plant upgrade of the concentrate to a super-concentrate by froth flotation for use in the direct reduction plant at DSC.

\section{MATERIALS AND METHODS}

\subsection{Materials}

The following reagents were used for the flotation aspect of the work: Flotigam EDA and Flotanol $\mathrm{M}$ both manufactured by CLARIANT were used as collector and frother respectively. 500g/t Starch, causticized with $25 \%$ sodium hydroxide, was used as depressant for iron minerals.500g/t. The sodium hydroxide was also used as $\mathrm{pH}$ regulator.

\subsection{Methods}

\subsubsection{Particle size distribution analysis}

The sinter grade iron ore, the flotation feed and the super-concentrate were subjected to screen distribution analysis on a set of sieve. The stack of sieve with the ore charged on the topmost sieve was clamped on the sieve shaker and shaken for 20 minutes. The weight retained on each sieve was then determined.

\subsubsection{Chemical analysis}

The iron, alumina and silica contents of the ore were determined by classical wet analysis as follows:

\subsubsection{Determination of total iron}

$0.2 \mathrm{~g}$ of the iron ore was weighed into a $25 \mathrm{ml}$ conical flask and $1.5 \mathrm{ml}$ distilled water was added to moisten the sample. $20 \mathrm{ml}$ of concentrated hydrochloric acid was then added and the flask was covered. After adding two drops of hydrofluoric acid, the mixture was placed on the hot plate and $50 \%$ stannous chloride $\left(\mathrm{SnCl}_{2}\right)$ was added until the solution turns colourless or green. The

mixture was covered with silica crucibles and allowed to boil on the hot plate until complete dissolution. - drops of ferroin indicator was added to the solution. The solution was removed 
from the hot plate, the cover and the wall of the conical flask were rinsed and $5 \% \mathrm{KMnO}_{4}$ added until yellow colour of ferroin appeared.

The solution was after heated to boiling and ferric iron was reduced by adding $15 \%$ stannous chloride solution until the yellow colour faded away. 10 to $15 \mathrm{mls}$ of 1:3 sulphuric acid was added, the solution was mixed and the wall of the flask was rinsed with distilled water until the total volume equalsled $100 \mathrm{mls}$. The solution was now cooled to about $25^{\circ} \mathrm{C}$ and $10 \mathrm{mls}$ of $2 \%$ mercuric chloride was added. The solution was allowed to stand for 5 minutes and $10 \mathrm{mls}$ of $0.02 \% \mathrm{Fe}$ indicator in $\mathrm{H}_{3} \mathrm{PO}_{4}(1: 4)$ was added. The solution was then titrated with $0.1 \mathrm{~N}$ Potassium di-chromate $\left(\mathrm{K}_{2} \mathrm{Cr}_{2} \mathrm{O}_{7}\right)$. The total $\mathrm{Fe} \%$ was finally determined with the formula:

$1 \mathrm{mls}$ of $0.1 \mathrm{~N} \mathrm{~K}_{2} \mathrm{Cr}_{2} \mathrm{O}_{7}=0.005585 \mathrm{~g} \mathrm{Fe}$

$$
\% \mathrm{Fe}=\frac{\text { titre of } \mathrm{K}_{2} \mathrm{Cr}_{2} \mathrm{O}_{7} \mathrm{X} \text { volume of } \mathrm{K}_{2} \mathrm{Cr}_{2} \mathrm{O}_{7} \mathrm{X} 100}{\text { weight of sample }}
$$

\subsubsection{Determination of silica content}

One gram of the sample was weighed into a platinum crucible and mixed thoroughly with the fusion mixture and then covered up with some of the fusion mixture. It was fused at a temperature of $950{ }^{\circ} \mathrm{C}$ in a muffle furnace and allowed to cool. The fused mass was extracted into a $400 \mathrm{ml}$ beaker using $50 \mathrm{ml}$ of $1: 1$ hydrochloric acid (HCI).

The extract was dehydrated on the hot plate using asbestos pad, after which it was cooled and $10 \mathrm{ml}$ concentrated HCI was added. Distilled water was used to make up the volume to the $50 \mathrm{ml}$ mark in the beaker. It was allowed to boil and filtered through No 541 filter paper. The residue was washed with 1:4 $\mathrm{HCl} 3$ times and with hot water several times until the residue was free from $\mathrm{HCl}$. The filter paper was folded into the platinum crucible and ignited at a temperature of $950{ }^{\circ} \mathrm{C}$ to constant weight in 20 minutes.

The crucible was then cooled in the desiccators and weighed as W1. Eight drops of 1:1 $\mathrm{H}_{2} \mathrm{SO}_{4}$ and $15 \mathrm{ml}$ of hydrofluoric acid (HF) were added to the residue in the crucible and it was heated in a sand bath placed on a hot plate to ensure slow evaporation. At the end, a copious fume was observed leaving the dried mass. The residue was now ignited in a muffle furnace at $950{ }^{\circ} \mathrm{C}$ for 20 minutes. It was cooled in a desiccators and the crucible weighed as W2. The percent weight of silica was calculated with the formula:

$$
\% \mathrm{SiO}_{2}=\frac{(W 1-W 2) \times 100}{W_{s}}
$$

Where: W1 = Weight of the platinum crucible with the material before hydrofluorisation. $\mathrm{W}_{\mathrm{s}}=$ Weight of the sample.

\subsubsection{Determination of alumina content}


One gram of the sample was weighed into a nickel crucible and 10 pellets of sodium hydroxide and a pinch of sodium carbonate was added. The mixture was melted over hot plate and finally fused over a low flame at $700{ }^{\circ} \mathrm{C}$ for 15 minutes.

The crucible was set aside and allowed to cool in air. When cooled, the crucible along with the content was dropped in a $250 \mathrm{ml}$ beaker and $100 \mathrm{ml}$ of hot distilled water was slowly added and boiled for 10 minutes. The crucible was removed with a glass rod and washed thoroughly with water into the beaker. The hot solution was filtered with No 40 filter paper into a $500 \mathrm{ml}$ conical flask.

The precipitate was then washed with hot water for 6 times to ensure that no sodium aluminate remains trapped in the precipitate. The filtrate was acidified with hydrochloric acid and $25 \mathrm{ml}$ standard EDTA was also added. The $\mathrm{pH}$ was adjusted to 5.5 with ammonium hydroxide and hydrochloric acid and the solution boiled for 15 minutes.

The solution was allowed to cool and $25 \mathrm{ml}$ acetic acid ammonium acetate buffer solution was added. The $\mathrm{pH}$ was checked and adjusted to 5.5 and drops of xylenol orange indicator were added and a lemon colour developed. Standard zinc acetate was used to tiltrate the solution. The colour changed from lemon yellow to purple indicating the end point. From the titre value the $\mathrm{Al}_{2} \mathrm{O}_{3}$ percentage was calculated with the formula:

$$
\% \mathrm{Al}_{2} \mathrm{O}_{3}=\frac{(A-T) x X x 100}{W_{s}}
$$

Where;

$\mathrm{A}=$ Volume of zinc acetate equivalent to $25 \mathrm{ml}$ EDTA solution.

$\mathrm{B}=$ Volume of zinc acetate solution required for titration after adding $25 \mathrm{ml}$ EDTA solution to the $5 \mathrm{ml}$ standard $\mathrm{Al}_{2} \mathrm{O}_{3}$ solution

$\mathrm{T}=$ The titre value of zinc acetate with the sample under Experiment

$\mathrm{W}_{\mathrm{s}}=$ Weight of sample

The results of the chemical analysis are presented in Table 7.

\subsection{Pilot Plant Beneficiation Method}

The sinter grade concentrate was fed into the ball mill $(\varnothing 100 \times 1500 \mathrm{~mm})$ at $500 \mathrm{~kg} / \mathrm{hr}$. The pilot plant flotation operation was carried out sequentially in a bank of flotation cells of $0.13 \mathrm{~m}^{3}$ capacity each as shown in Fig. 1. The sinter grade iron ore was treated with $110 \mathrm{~g} /$ ton of Flotigam EDA as collector and $10 \mathrm{~g} /$ ton of flotanol $\mathrm{M}$ frother. The slurry $\mathrm{pH}$ was adjusted with sodium hydroxide to be 10.5 and treated with maize starch causticised with $25 \% \mathrm{NaOH}$ as the depressant for iron oxide. The slurry at $50 \%$ solids was then conditioned in the bank of 4 roughing flotation cells for 2 minutes. The charged slurry having $40 \%$ solid was deslimed at $5 \mu \mathrm{m}$ size using $2 \mathrm{~mm}$ hydrocyclones operating at 50 Psi pressure. The cyclone underflow having $33 \%$ solids was delivered to the 4 cleaner cells and cleaned for two minutes. The cleaned slurry at $33 \%$ solids 
was after re-cleaned in the bank of 2 re-cleaning cells for another 2 minutes. The mass balance was done by taking samples with pulp densities cans at some points in the process lines and working out the corresponding weight $\%$ at each point.

\section{RESULTS AND DISCUSSION}

\subsection{Results}

The results obtained on the chemical composition and particle size analyses are presented in Tables 1 to 7 , while the flotation flowsheet, mass balance for the process and curves for the particle size distributions are presented in Figures 1 to 5.

Table 1: Grain size distribution of Itakpe iron ore sinter grade concentrate.

\begin{tabular}{|lllll|}
\hline S/N & $\begin{array}{l}\text { Sieve } \\
\text { sizes }(\mu \mathrm{m})\end{array}$ & $\begin{array}{l}\text { Weight\% } \\
\text { retained } \\
\text { on sieve }\end{array}$ & $\begin{array}{l}\text { Cumulative\% } \\
\text { undersize }\end{array}$ & $\begin{array}{l}\text { Cumulative\% } \\
\text { oversize }\end{array}$ \\
\hline 1. & -710 & 11.13 & 88.87 & 11.13 \\
2. & $-500+355$ & 11.81 & 77.06 & 22.94 \\
3. & $-355+250$ & 14.39 & 62.67 & 37.33 \\
4. & $-250+180$ & 18.50 & 44.17 & 55.83 \\
5. & $-180+125$ & 16.79 & 27.38 & 72.62 \\
6. & $-125+90$ & 13.00 & 14.38 & 85.62 \\
7. & $-90+63$ & 8.04 & 6.34 & 93.66 \\
8. & $-63+45$ & 4.22 & 2.12 & 97.88 \\
9. & -45 & 2.00 & 0.65 & 99.35 \\
\hline
\end{tabular}

Table 2: Gates-Gaudin-Schuhmann and Rosin Rammler data for Grain size distribution of Itakpe iron ore sinter grade concentrate.

\begin{tabular}{llllll}
\hline S/N & $\begin{array}{l}\text { Cumulative } \\
\% \text { undersize }\end{array}$ & $\begin{array}{l}\text { Log } \\
\text { Cumulative } \\
\text { undersize } \\
\left(\times 10^{-1}\right)\end{array}$ & $\begin{array}{l}\text { Log } \\
\text { Cumulative } \\
\text { Rosin } \\
\text { Rammler. }\end{array}$ & $\begin{array}{l}\text { Sieve } \\
\text { sizes } \\
(\mu \mathrm{m})\end{array}$ & $\begin{array}{l}\text { Log } \\
\text { sieve } \\
\text { aperture. }\end{array}$ \\
\hline 1. & 88.87 & 19.5 & 0.34 & -710 & 2.85 \\
2. & 77.06 & 18.90 & 0.16 & $-500+355$ & 2.70 \\
3. & 62.67 & 18.00 & -0.006 & $-355+250$ & 2.55 \\
4. & 44.17 & 16.50 & -0.23 & $-250+180$ & 2.40 \\
5. & 27.38 & 14.40 & -0.49 & $-180+125$ & 2.26 \\
6. & 14.38 & 11.60 & -0.81 & $-125+90$ & 2.10 \\
7. & 6.34 & 8.00 & -1.17 & $-90+63$ & 1.95 \\
8. & 2.12 & 3.30 & -1.66 & $-63+45$ & 1.80 \\
9. & 0.65 & -1.90 & -2.19 & -45 & 1.65 \\
\hline
\end{tabular}


Table 3: Grain size distribution of sinter grade pilot plant flotation feed.

\begin{tabular}{lllc}
\hline S/N & $\begin{array}{l}\text { Sieve sizes. } \\
(\mu \mathrm{m})\end{array}$ & $\begin{array}{l}\text { Flotation feed, } \\
\text { cumulative }(\%) \\
\text { undersize. }\end{array}$ & $\begin{array}{l}\text { Flotation feed, } \\
\text { cumulative }(\%) \\
\text { oversize. }\end{array}$ \\
\hline 1. & -500 & 99.83 & 0.17 \\
2. & $-355+250$ & 99.20 & 0.80 \\
3. & $-250+180$ & 99.58 & 0.42 \\
4. & $-180+125$ & 97.58 & 2.42 \\
5. & $-125+90$ & 90.33 & 9.67 \\
6. & $-90+63$ & 74.37 & 25.63 \\
7. & $-63+53$ & 42.94 & 57.06 \\
8. & -53 & 8.22 & 91.78 \\
\hline
\end{tabular}

Table 4: Gates-Gaudin-Schuhmann and Rosin Rammler data for Grain size distribution of Itakpe iron ore sinter grade pilot plant feed.

\begin{tabular}{llllll}
\hline S/N & $\begin{array}{l}\text { Cumulative } \\
\text { undersize }\end{array}$ & $\begin{array}{l}\text { Log } \\
\text { Cumulative } \% \\
\text { undersize }\end{array}$ & $\begin{array}{l}\text { Log } \\
\text { Cumulative Rosin } \\
\text { Rammler }\left(\mathrm{x} \mathrm{10} 0^{-1}\right)\end{array}$ & $\begin{array}{l}\text { Sieve } \\
\text { sizes } \\
(\mu \mathrm{m})\end{array}$ & $\begin{array}{l}\text { Log } \\
\text { sieve } \\
\text { aperture }\end{array}$ \\
\hline 1. & 99.83 & 1.999 & 8.10 & -500 & 2.70 \\
2. & 99.20 & 1.996 & 6.80 & $-355+250$ & 2.55 \\
3. & 99.58 & 1.998 & 7.40 & $-250+180$ & 2.40 \\
4. & 97.58 & 1.989 & 5.70 & $-180+125$ & 2.26 \\
5. & 90.33 & 1.956 & 3.70 & $-125+90$ & 2.10 \\
6. & 74.37 & 1.871 & 1.30 & $-90+63$ & 1.95 \\
7. & 42.94 & 1.633 & -2.50 & $-63+53$ & 1.80 \\
8. & 8.22 & 0.915 & -0.107 & -53 & 1.72 \\
\hline
\end{tabular}

Table 5: Grain size distribution of pilot plant super-concentrate.

\begin{tabular}{llcl}
\hline S/N & $\begin{array}{l}\text { Sieve } \\
\text { sizes } \\
(\mu \mathrm{m})\end{array}$ & $\begin{array}{l}\text { Super-concentrate, } \\
\text { cumulative }(\%)\end{array}$ & $\begin{array}{l}\text { Super-concentrate, } \\
\text { cumulative }(\%) \\
\text { undersize }\end{array}$ \\
\hline 1. & -500 & 99.76 & 0.24 \\
2. & $-355+250$ & 99.70 & 0.30 \\
3. & $-250+180$ & 9.22 & 0.78 \\
4. & $-180+90$ & 97.34 & 2.66 \\
5. & $-90+63$ & 81.13 & 18.87 \\
6. & $-63+45$ & 55.19 & 44.81 \\
7. & -45 & 30.57 & 69.43 \\
\hline
\end{tabular}


Table 6: Gates-Gaudin-Schuhmann and Rosin Rammler data for Grain size distribution of Itakpe iron ore super-concentrate.

\begin{tabular}{lcllll}
\hline S/N & $\begin{array}{l}\text { Cumulative\% } \\
\text { undersize }\end{array}$ & $\begin{array}{l}\text { Log } \\
\text { Cumulative\% } \\
\text { undersize }\end{array}$ & $\begin{array}{l}\text { Log } \\
\text { Cumulative } \\
\text { Rosin Rammler } \\
\left(\times 10^{-1}\right)\end{array}$ & $\begin{array}{l}\text { Sieve } \\
\text { sizes } \\
(\mu \mathrm{m})\end{array}$ & $\begin{array}{l}\text { Log } \\
\text { sieve } \\
\text { aperture }\end{array}$ \\
\hline 1. & 99.76 & 1.999 & 7.80 & -500 & 2.70 \\
2. & 99.70 & 1.999 & 7.60 & $-355+250$ & 2.55 \\
3. & 99.22 & 1.997 & 6.90 & $-250+180$ & 2.40 \\
4. & 97.34 & 1.988 & 5.60 & $-180+125$ & 2.26 \\
5. & 81.13 & 1.909 & 2.20 & $-90+63$ & 1.95 \\
6. & 55.19 & 1.74 & -0.95 & $-63+45$ & 1.80 \\
7. & 30.57 & 1.49 & -4.40 & -45 & 1.65 \\
\hline
\end{tabular}

Table 7: Chemical analyses of Itakpe sinter concentrate and super-concentrate grades.

\begin{tabular}{|c|c|c|c|c|}
\hline \multirow[b]{2}{*}{$\begin{array}{l}\text { Parameters } \\
(\%)\end{array}$} & \multirow[b]{2}{*}{$\begin{array}{l}\text { Itakpe sinter } \\
\text { grade }\end{array}$} & \multicolumn{3}{|c|}{ Stages in pilot plant flotation } \\
\hline & & Roughing & Cleaning & Re-cleaning \\
\hline $\mathrm{Fe}$ & 63.63 & 66.66 & 66.51 & 65.44 \\
\hline $\mathrm{SiO}_{2}$ & 5.90 & 3.71 & 3.88 & 4.55 \\
\hline $\mathrm{Al}_{2} \mathrm{O}_{3}$ & 0.72 & 0.51 & 0.51 & 0.60 \\
\hline $\mathrm{SiO}_{2}+\mathrm{Al}_{2} \mathrm{O}$ & 6.62 & 4.22 & 4.39 & 5.15 \\
\hline
\end{tabular}




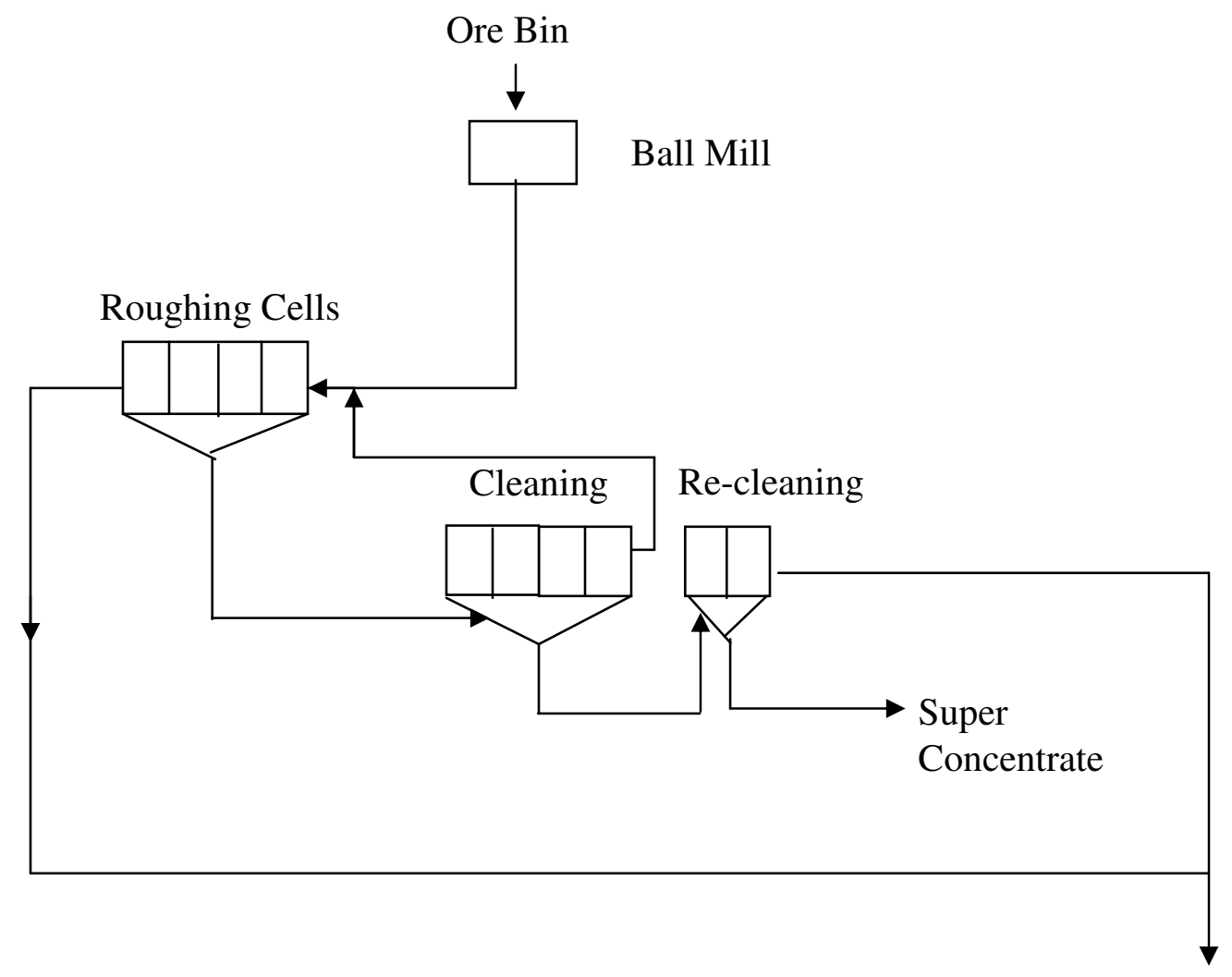

Fig.1: Pilot Plant Flotation Scheme.

Itakpe Sinter Grade

Concentrate (as received).
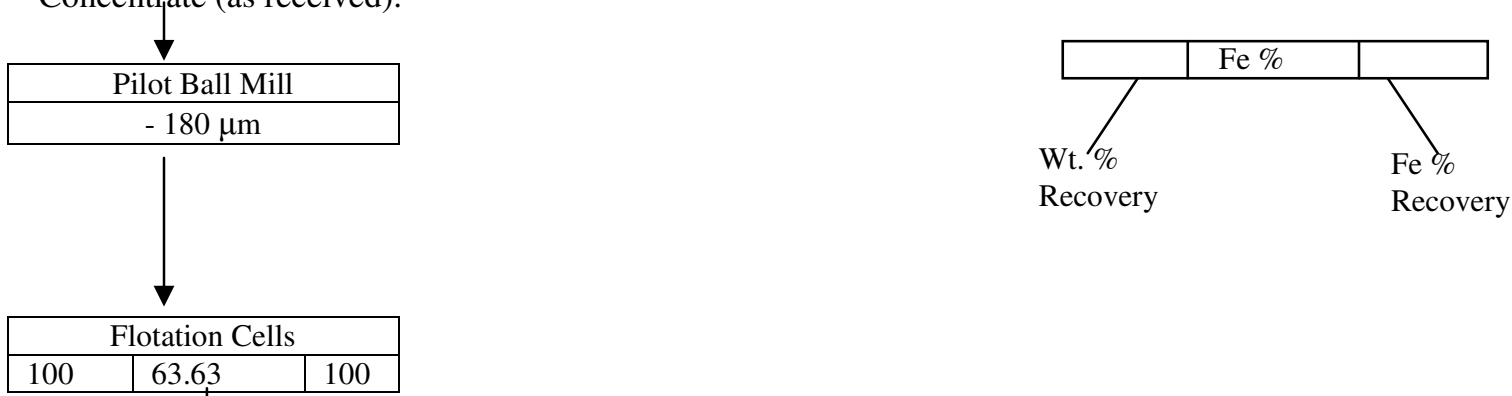

Superconcentrate

\begin{tabular}{|l|l|l|}
\hline 96.10 & 65.21 & 98.50 \\
\hline
\end{tabular}

Tailings

\begin{tabular}{|l|l|l|}
\hline 3.90 & 24.47 & 1.50 \\
\hline
\end{tabular}

Fig. 2 Overall Mass Balance Flowsheet for the Production of Itakpe Superconcentrate by Froth Flotation. 

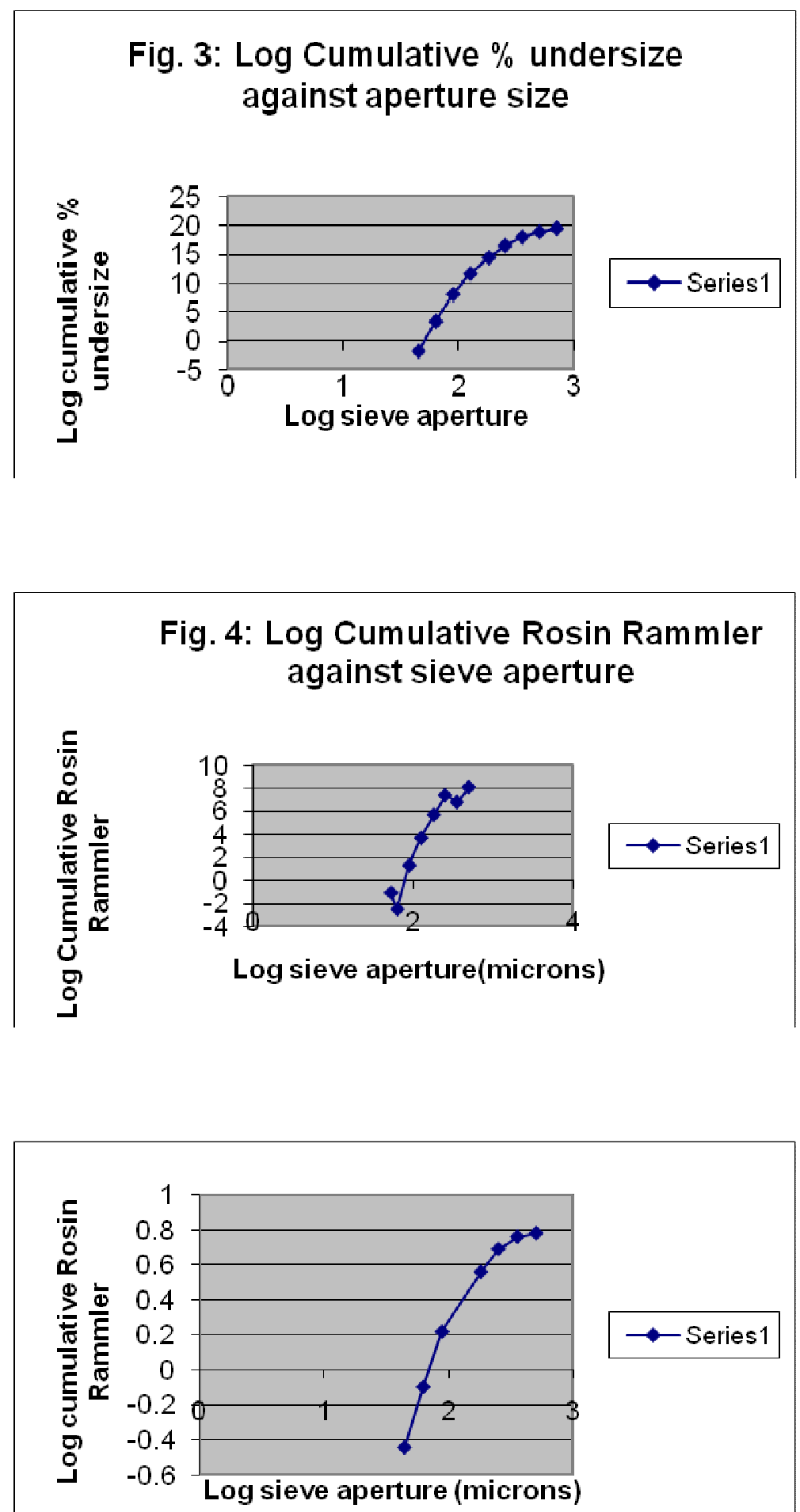

Fig. 5: Log cumulative Rosin Rammler against Log sieve aperture 


\subsection{Discussion of Results}

Particle size distribution analysis gave $77.06 \%$ and $99.83 \%, 27.38 \%$ and $97.88 \%, 2.12 \%$ and $42.94 \%$ for fractions of sinter grade concentrate and pilot plant feed passing $500 \mu \mathrm{m}, 180 \mu \mathrm{m}$ and $63 \mu \mathrm{m}$ sieves. These results indicate that ball mill grinding produced a great increase in the cumulative undersize at $180 \mu \mathrm{m}$ from $27.38 \%$ to $97.88 \%$ and at $63 \mu \mathrm{m}$ from $2.12 \%$ to $42.94 \%$. The cumulative under sizes obtained at $500 \mu \mathrm{m}, 180 \mu \mathrm{m}$ and $45 \mu \mathrm{m}$ for the super-concentrate were $99.76 \%, 97.34 \%$ and $30.51 \%$, respectively. The $30.57 \%$ obtained for the super-concentrate at $45 \mu \mathrm{m}$ is far higher than $0.65 \%$ for the pilot plant feed. The results obtained showed that the superconcentrate obtained meet the specification of $30 \%$ minimum of grains passing 45 microns to produce pellets for direct reduction.[7] The cumulative percent plots for the grain size distribution gave median size of about $178 \mu \mathrm{m}, 162 \mu \mathrm{m}$ and $150 \mu \mathrm{m}$ with approximate cumulative undersize percents of $26.30 \%, 95.46 \%$ and $94.76 \%$, for the sinter grade concentrate, ball mill discharge and super-concentrate, respectively. These results indicate a progressive decrease in size and rapid increase in cumulative percent passing the respective sieve apertures.

The Fe content of $63.63 \%$ determined for Itakpe sinter grade concentrate to be upgraded to a super-concentrate is higher than $63.22 \%$ in use at the China Anshan iron and steel company and exceeds the standard specification of $63 \%$ for use at the Ajaokuta steel plant blast furnace. However, the silica and alumina contents of $5.90 \%$ and $0.72 \%$, respectively; obtained for the Itakpe concentrate gives a total acidic oxide content of $6.62 \%$ that is far above the upper limit of $3.0 \%$ for Midrex direct reduction process. For some other standards, the total acid oxides include titanium oxide.[8] These analysis results indicate that Itakpe concentrate needs to be further upgraded for direct reduction by the Midrex process.

For the roughing, cleaning and re-cleaning stages of the flotation process, Fe and total acid oxides of $66.66 \%$ and $4.22 \%, 66.51 \%$ and $4.39 \%$ and $65.44 \%$ and $5.15 \%$, respectively were obtained. These results indicate that the intermediate products at roughing and cleaning stages satisfy the range of $66 \%$ to $66.8 \% \mathrm{Fe}$ content required for the Midrex process, while the final recleaning stage gave a $\mathrm{Fe}$ content of 65.44 that fall below this range. Similarly, the total acid oxides increased from $4.22 \%$ at roughing stage to $4.39 \%$ and $5.15 \%$ at the last two stages. The Fe content of $66.66 \%$ determined for the roughing stage falls within the range of $66-66.8 \%$ for direct reduction at DSC. Thus, the result suggests that the cleaning and re-cleaning stages are not necessary to upgrade Itakpe sinter grade ore to super-concentrate by flotation. Although the gangue contents in the three stages are slightly above the required standard of $3.5 \%$ maximum for direct reduction, Itakpe enhanced grade concentrates of up to about 5\% gangue have been successfully processed at DSC. 


\section{CONCLUSIONS}

The sinter grade of the Nigerian Itakpe iron ore that assayed $63.63 \% \mathrm{Fe}$ and total acid gangue of $6.62 \%$ has been successfully upgraded to a super-concentrate with a higher Fe content of $66.66 \%$ and lower acid gangue of $4.22 \%$ at the roughing stage of the pilot plant froth flotation operation. The Fe content meets the requirement for a Midrex-grade super-concentrate, while the acid gangue content only slightly exceeds the upper limit of 3.5\%. However, Itakpe sinter concentrate with up to $5 \%$ acid gangue has been successfully reduced at DSC Midrex plant.

\section{REFERENCES}

1. Umunakwe, P.U.(1985). "Developing a new mine- The Itakpe case". Proc. Annual Conf. of Nigeria Mining and Geosciences Society, Jos, Nigeria.

2. (http://www.midrex.com/uploads/documents/Direct, 2008).

3. (http://www.columbia.edu/itc/ldeo/lackner/E4900/Themelis3.pdf, 2008).

4. (http://www.miningbasics.com/html/fundamentals_of_froth_flotation.php, 2008).

5. Houot, R. (1983). "Beneficiation of iron ore by flotation-Review of industrial and potential applications". Int. J. of mineral processing, 10, 183-204

6. Wills, B.A.(1992). "Mineral Processing Technology", $5^{\text {th }}$ Edn., Pergamon Press, Oxford.

7. Raw Materials and Products Specifications for Steel Industries, Federal Ministry of Mines, Power and Steel, Abuja, Nigeria, 1994

8. (http://www.columbia.edu/itc/ldeo/lackner/E4900/Themelis3.pdf, 30 ${ }^{\text {th }}$ October 2008). 